\title{
Christelike norme en waardes \\ in onderwys en opleiding
}

Wouter C van Wyk (jr)

Randse Afrikaanse Universiteit

\begin{abstract}
This article investigates the way Christian norms and values can be realised in the context of education and training. The article starts with a survey of the ways in which, in the previous political dispensation, Christian norms and values were incorporated in career training, in tertiary education and in the programmes of primary and secondary schools. Education and training, however, now have to operate in a new environment, which will be greatly determined by the Bill of Human Rights in the new constitution, the Reconstruction and Development Plan and the White Paper on Education and Training. After examining the implications of this new environment the article concludes by identifying opportunities for actively furthering Christian norms and values within the new environment of education and training in South Africa.
\end{abstract}

\section{PROBLEEMSTELLING}

Hoe kan Christelike norme en waardes in die onderwysbestel tot hulle reg kom? Dit is die sleutelvraag by die bespreking van Christelike norme en waardes in onderwys en opleiding. Om hierdie vraag te kan beantwoord word ' $n$ aantal sleutelterme eers nader omskryf. Daarna volg 'n bespreking van die wyse waarop Christelike norme en waardes in die onderwysbestel van die vorige politieke bedeling tot uitdrukking gekom het. Vervolgens word die nuwe omgewing waarbinne onderwys en opleiding funksioneer, ondersoek. In die konklusie word daar gepoog om die aanvanklike vraag in die lig van die omgewingsverkenning te beantwoord.

\section{DEFINISIES}

Aangesien die titel van hierdie artikel 'n paar terme bevat waaroor daar heel moonlik misverstand kan bestaan, word die wyse waarop die sleutelterme voorts verstaan en gebruik word ter aanvang omskryf.

* Voordrag gelewer op 16 Junie 1995 in Bloemfontein tydens die Afrikaanse Onderwyskongres met die tema: Onderwys en opleiding in toekomsperspektief. 
In die uitdrukking 'norme en waardes' word die twee woorde eintlik wedersyds verklarend en versterkend gebruik, en die uitdrukking dui op ' $n$ maatstaf waaraan alle dinge, en dus ook die teorie en praktyk van onderwys en opleiding, gemeet word. Dit is weliswaar nie so maklik om die spesifieke aard van 'Christelike' norme en waardes aan te dui nie, maar in hierdie artikel word onder hierdie term breedweg verstaan ' $n$ waardestelsel wat die Bybel as die gesaghebbende Woord van God anvaar en wat spruit uit geloof in dieDrie-enige God.

Die kombinasie van die begrippe 'onderwys en opleiding' is die produk van navorsing en gespreksdokumente binne die dampkring van die ANC (bv A policy framework for education and training, Januarie 1994) en vind ook neerslag in die onlangse Witskrif oor onderwys en opleiding van die Regering van Nasionale Eenheid (Maart 1995). Ten spyte van ' $n$ veelbelowende inleiding tot die hoofstuk, verskaf hoofstuk twee van hierdie witskrif nie duidelike definisies van die twee terme nie: 'Opleiding is ' $n$ noodsaaklike deel van baie leerprogramme wat in skole, onderwysers-kolleges, tegniese kolleges, technikons en universiteite aangebied word' (Witskrif 1995:15). Die term 'onderwys' word glad nie gedefinieer nie. Uit die teenstellings later in die volgende aanhaling uit dieselfde hoofstuk kan afgelei word dat die eerste term telkens na 'onderwys' verwys, terwyl die tweede (kontrasterende) term op 'opleiding' slaan: "n Geïntegreerde benadering impliseer ' $n$ siening van die leerproses wat ' $n$ starre verdeling verwerp tussen "akademies" en "toegepas", "teorie" en "praktyk", "kennis" en "vaardighede", "kop" en "hand" (Witskrif 1995:15).

$\mathrm{Na}$ aanleiding hiervan gaan ek in hierdie artikel dus van die veronderstelling uit dat 'onderwys' verwys na akademiese onderrig by instansies wat mense vir werk in ' $n$ ander omgewing voorberei, terwyl 'opleiding' van toepassing is op spesifieke beroepsonderrig deur ' $n$ instansie wat mense oplei met die oog op diens wat hulle binne daardie selfde instansie of arbeidsektor sal lewer. Uiteraard kan hierdie onderskeid ook nie in alle gevalle gehandhaaf word nie.

\section{CHRISTELIKE NORME EN WAARDES IN DIE VORIGE ONDERWYS- BESTEL}

\subsection{Christelike norme en waardes in opleiding}

Die maklikste beginpunt vir hierdie oorsig is waarskynlik beroepsopleiding: in hierdie veld kan daar met vrymoedigheid gesê word dat Christelike norme en waardes geen plek in die kurrikulum gehad het nie. Ek is nie bewus van ambagsmanne of tegnici van enige maatskappy of in enige werksveld wat Christelike waardes as deel van hulle opleiding behandel het nie, en hierdie toedrag van sake is bevestig in gesprekke met ingeligte persone wat by verskillende groot instansies werksaam is. 
In baie gevalle was (en is) die etiek in die werkplek breedweg in ooreenstemming met die Christelike etiek, met ' $n$ personeelkode wat waardes soos eerlikheid, hardwerkendheid, diensvaardigheid, onselfsugtigheid, verdraagsaamheid, en so meer aanmoedig. Dit kom ook tot uitdrukking in kursusse oor arbeidsverhoudinge, kliëntediens en so meer. Hieroor moet egter twee opmerkings gemaak word: eerstens is die waardes wat wel (implisiet of eksplisiet) in die opleiding tot uitdrukking gekom het waarskynlik die vrug van Christene se lewenshouding eerder, as die resultaat van doelbewuste kurrikulering. Tweedens sou die verskil tussen 'n Christelike, Joodse en Islamitiese werksetiek moeilik aangetoon kon word, sodat ons waarskynlik eerder met ' $n$ algemeen aanvaarde en erkende werksetiek te doen het as met ' $n$ spesifiek Christelike werksetiek.

\subsection{Christelike norme en waardes in tersiêre onderwys}

Dieselfde geld grootliks in die tersiêre onderwyssektor en veral aan universiteite en technikons. Die Christelike waardestelsel is meestal nie geïnstitusionaliseer in die wette en statute van die inrigtings nie, en speel ook nie ' $n$ rol in die samestelling van studente se kursusse nie. Weens die besondere samestelling van die studente- en personeelkorps kom die Christelike geloof en waardestelsel in die praktyk wel na vore. In hierdie verbaind kan daar verwys word na amptelike seremoniële openings van openbare geleenthede soos gradeplegtighede en vergaderings, beskikbaarstelling van fasiliteite aan studentepredikante en kultuurorganisasies en geleenthede aan Christelike studentegroepe om eredienste en sendingaksies te organiseer. Die Christelike geloof en waardestelsel het dus nie in die onderrigprogram ' $n$ rol gespeel nie, maar wel spontaan in die lewe van die betrokke onderwysgemeenskap. Aan talle tersiêre inrigtings is daar wel vakke soos Bybelkunde wat met die Christelike godsdiens of die Bybel verband hou, gedoseer. Hierdie vakke was egter nie 'n verpligte deel van enige graad- of diplomakursus nie, maar is vrywillig deur geïnteresseerde studente geneem. In die geval van onderwysstudente (by universiteite en onderwyskolleges) was/is Godsdiensonderrig wel ' $n$ verpligte vak, maar slegs ' $n$ bywoningskursus, en nie een waarvan suksesvolle eksamenresultate nodig was/is vir die voltooiing van die graad (of diploma) nie. Die inslag van hierdie kursusse was ook nie eties voorskriftelik nie, maar bloot informerend van aard.

Die een uitsondering op die reël is die Potchefstroomse Universiteit vir Christelike Hoër Onderwys. Soos die naam van die universiteit uitdruklik aantoon, het hierdie universiteit ' $n$ eksplisiete Christelike karakter aangeneem wat tot uiting gekom het in die universiteit se statute, in die besluitnemingsproses rondom (nuwe) beleidsrigtings, in die aanstelling van personeel en ook in die kurrikulering van studente se graadkursusse. Alle studente van die universiteit moes in hulle tweede en derde studiejaar 
jaarkursusse in 'Interfakultêre wetenskapsleer' neem - 'n kursus wat op die Christelike wetenskapsfilosofie van Dooyeweerd en Stoker berus. Volgens hierdie filosofie bepaal ' $n$ Christen se geloof sy totale verwysingsraamwerk, en laat dit hom ook oor die wetenskap anders oordeel as ' $\mathrm{n}$ nie-Christen.

Tot watter mate die PU vir CHO se uitdruklik Christelike vertrekpunt ' $n$ invloed uitgeoefen het op die waardestelsel van sy studente is uiteraard baie moeilik om te bepaal. Daar kan in elk geval ook aanvaar word dat die soort-soek-soort-beginsel ook by potensiële studente ' $n$ rol gespeel het - studente wat hulleself maklik met die Christelike waardestelsel van die universiteit kon identifiseer, het bykomende motivering gehad om aan die PU vir CHO te gaan studeer: Aan die ander kant het studente wat hulle nie daarmee kon identifiseer nie, waarskynlik in die meeste gevalle by voorbaat ' $n$ meer neutrale (sekulêre?) inrigting gekies.

\subsection{Christelike norme en waardes in skoolonderrig}

Hierdie is die een onderwyssektor waarvan Christelike norme en waardes in die vorige bedeling uitdruklik die grondslag gevorm het. Die opvoedkundige rasionaal daaragter was dat onderrig nie net kennisoordrag is nie, maar die omvattende vorming van die kind tot 'n verantwoordelike volwassene veronderstel. Onderwys op skool is meer as onderrig - dit sluit ook opvoeding in. Onderwys het das nie net ' $n$ kognitiewe dimensie nie, maar ook ' $n$ etiese.

Die normatiewe raamwerk van die onderwys moet vanselfsprekend aansluit by die Christelike beginsels wat in die ouerhuis geld. Hierdie siening is dus gebaseer op die veronderstelling dat Afrikaners Christene is. Meer nog, die basis van die Christelike waardestelsel wat in die onderwys tot uitdrukking moes kom, was vir Afrikaners meer as net die Bybel, en het ook die reformatoriese belydenisskrifte en die drie Afrikaanse susterskerke se huweliksformulier, doopformulier en nagmaalsformulier ingesluit (vgl Gerber 1978:141-62).

In die Afrikanergemeenskap het Christelik-nasionale onderwys naderhand kanoniek geword. Die veronderstellings en beginsels onderliggend daaraan is nie meer bevraagteken nie, en die implikasies van veranderde omstandighede en samelewingspatrone is nie verreken nie. Enige ander benadering tot onderwys was deel van ' $n$ vreeslike bedreiging: 'Die bedreiginge vir ' $n$ Christelike en nasionale opvoeding blyk dan een groot meesterplan te wees van Satan wat met ' $n$ slinkse set kom in sy poging om die kerk van Christus te vernietig' (Roos 1978:174).

Die Christelike karakter van skoolonderrig is ook in wetgewing vasgelê: in die (blanke) Volksraad se wet op onderwysaangeleenthede (wet 70 van 1988, artikel 62), in die wet op onderwys vir Kleurlinge (wet 47 van 1963, artikel 34, geamendeer in regulasie R 1898 van 21 November 1963), en in die wet op onderwys en opleiding (wet 90 van 1979, artikel 3). 
In terme van hierdie wetgewing het Bybelonderrig ' $n$ vaste plek in die kurrikulum van skole gekry. In die skoolpraktyk het die Christelike geloof en die gepaardgaande waardestelsel ' $n$ groot rol gespeel. Amptelike skoolfunksies is gewoonlik met Skriflesing en gebed geopen, weeklikse 'saalopenings' en '-afsluitings' het gewoonlik ' $n$ preek van die een of ander aard ingesluit, elke dag se onderrigaktiwiteite is begin en afgesluit met gebed. Verder het organisasies met ' $n$ Christelike inslag soos die Afrikaanse Christen Studente Vereniging en die Voortrekkers ten volle deel uitgemaak van skole se buitemuurse program.

Laastens het die leiding, voorbeeld en getuienis van Christen-onderwysers, meestal informeel, ' $n$ belangrike rol gespeel om die Christelike waardestelsel aan leerlinge oor te dra. Trouens, hierdie onderwysers is myns insiens die heel belangrikste faktor in die oordra van Christelike norme en waardes aan die kind.

\subsection{Onderwysinisiatiewe van die vorige regering}

Die vorige regering het twee belangrike ondersoeke na die onderwys gedoen gedurende die afgelope vyftien jaar: die ondersoek deur die Raad vir Geesteswetenskaplike Navorsing na die onderwys (Onderwysvoorsiening in die RSA, 1981) en die Departement Nasionale Onderwys se Onderwysvernuwingstrategie (1992). Hoewel nie een van hierdie ondersoeke op die plek van ' $n$ Christelike waardestelsel in die onderwys afgestem was nie, het albei ondersoeke ' $n$ paar belangrike beginsels geïdentifiseer. Albei ondersoeke getuig van begrip vir die groter godsdienstige diversiteit waarmee daar in die onderwys rekening gehou moet word.

Die RGN-verslag het ' $n$ aantal konsensusbeginsels vir onderwysvoorsiening geïdentifiseer waarvan die relevante beginsels vervolgens aangehaal word:

Beginsel 1: Gelyke onderwysgeleenthede met insluiting van gelyke onderwysstandaarde sal vir elke inwoner ongeag ras, kleur, geloof of geslag deur die Staat doelgerig nagestreef word.

Beginsel 2: Die onderwys verleen positiewe erkenning aan sowel die gemeenskaplikheid as die diversiteit van die religieuse en kulturele leefwyse en die tale van die inwoners.

Beginsel 3: Die onderwys verleen positiewe erkenning aan die keusevryhede van die individu, ouers en organisasies in die samelewing. 
Een van die implikasies van hierdie beginsels wat later in die verslag uitgespel word, is dat die:

verlening van positiewe erkenning aan sowel die gemeenskaplikheid as die diversiteit van religieuse en kulturele leefwyse en die tale van die inwoners, impliseer dat die stelsel van onderwysvoorsiening soepel en buigsaam sal moet wees wat die beheer- en organisasiestruktuur betref en dat beheer- en organisasiefunksies en -bevoegdhede duidelik omskryf sal moet wees.

(RGN-verslag 1981:17).

Die laaste onderwysinisiatief van die vorige regering het uitgeloop op die Onderwysvernuwingstrategie (OVS) van die Departement Nasionale Opvoeding (1992). Hierdie dokument is primêr op ' $\mathrm{n}$ ekonomies haalbare bestuursmodel vir die onderwys afgestem, maar identifiseer tog ook ' $n$ aantal beginsels vir onderwysbestuur wat belangrike konsekwensies vir die geloofsinslag van onderwysinstellings inhou. Die O V S voorsien in breë trekke 'n onderwysstelsel 'met ' $n$ sentrale onderwysowerheid en streekowerhede wat oor eie gesag en besluitnemingsbevoegdheid beskik' .... 'Dit sal nasionale eenheid bevorder terwyl dit ook voorsiening maak vir partikuliere godsdiens-, taalen kultuurbehoeftes' (OVS 1992:ix).

Die volgende stelling word dan gemaak as die dokument se tweede standpunt oor ' $n$ aanvaarbare model vir die onderwysstelsel:

[D]ie nuwe onderwysstelsel moet nasionale eenheid bevorder en tot uitdrukking laat kom. Met inagneming van die nie-rassige basis van 'n nuwe onderwysstelsel moet daar ook voorsiening gemaak word vir die akkomodering van verskeidenheid op grond van internasionaal erkende en opvoedkundig relevante basiese menseregte soos moedertaalonderrig, godsdiensvryheid en die beoefening en oordrag van ' $n$ eie kultuur. Vryheid van assosiasie moet derhalwe ' $n$ hoeksteen van ' $n$ nuwe onderwysstelsel vorm.

(OVS 1992:17-8)

\subsection{Christelike norme en waardes in die vorige onderwysbestel - samevatting en kritiek}

Christelike norme en waardes het eintlik net in die skoolsituasie ' $n$ prominente rol gespeel. Ongelukkig is die wyse waarop Christelike norme en waardes in ons skole 
gefigureer het, ook nie bo kritiek verhewe nie. Aan die een kant het die totale onderrig duidelik van die veronderstelling uitgegaan dat alle Afrikaners dieselfde Protestantse (en meer spesifiek Calvinistiese) geloofsoortuigings deel. Daar is in die teorie geen, en in die praktyk weinig, ruimte gelaat vir kinders met ' $n$ ander godsdienstige agtergrond - Christene uit Pinksterkerke, Rooms-Katolieke, Moslems en selfs buitekerklikes (ateïste) - nie. 'Die basis van die Afrikaanse lewensopvatting, van sy geskiedenis, sy kultuur en die hele aard en wese van sy volk word gevind in die Christelike aard daarvan. Die Afrikaners is by uitstek kerk-mens wat die Bybel as die onfeilbare Woord van God aanvaar en wat hom ook daardeur laat lei' (Roos 1978:175).

Aan die ander kant het gesegregeerde onderwys dit maklik (selfs vanselfsprekend) gemaak om die etniese, godsdienstige en morele waardestelsels van ander bevolkingsgroepe en gemeenskappe te ignoreer of aan hoofstroom-Afrikaners se waardestelsel te onderwerp. 'Omdat die Afrikaner besef dat hy in ' $n$ eie gemeenskap God en sy naaste die beste kan dien, gun hy so ' $n$ eie ruimte en gemeenskap ook vir diegene naas hom sodat hulle daar in ' $n$ wrywingsvrye gemeenskap as ' $n$ etniese volk saam kan woon. Aangesien die Christen-Afrikaner wil hê dat hierdie beskawing ook Christelik en nasionaal moet wees, het hy nog altyd die roeping aanvaar om ook aan hierdie volke die evangelie van Jesus Christus te bring' (Roos 1978:176).

Die praktiese ervaring van Godsdiensonderrig en Bybelkunde op skool was ook nie altyd positief nie. Die wetgewers én die kerke was tevrede om die verantwoordelikheid hiervoor aan die skole oor te laat, en die leerplanne was soms onsamehangend of ' $n$ onbevredigende vermyding van twispunte tussen die drie tradisionele Afrikaanse susterskerke. Waar Godsdiensonderrig of Bybelkunde deur toegewyde deurleefde Christenonderwysers aangebied is, het dit vrug afgewerp. Godsdiensonderrig, veral, was egter nie " $n$ eksamenvak nie, en was daarom dikwels nóg vir onderwyser nóg vir leerlinge ' $n$ prioriteit. Die resultaat was gevolglik eerder teenproduktief vir die oordra van Christelike norme en waardes.

\section{NUWE ONDERWYS- EN OPLEIDINGSOMGEWING WAARBINNE CHRISTELIKE WAARDES MOET GESTALTE AANNEEM}

\subsection{Die handves van menseregte in die oorgangsgrondwet van die Republiek van Suid-Afrika}

Die breë raamwerk waaraan die totale gemeenskapslewe in die nuwe bedeling georiënteer moet word, is die Handves van Menseregte wat ook in die tussentydse grondwet van die Republiek van Suid-Afrika vervat is. Die Handves van Menseregte gaan uit van die gelykheid van alle mense voor die reg, en verbied verskillende vorme van diskriminasie, waaronder diskriminasie op grond van geloof, uitdruklik. Die Handves beskerm egter die reg op vryheid van gewete, godsdiens, denke, oortuiging en opinie. 
Die vryheid om godsdienstige oortuigings vryelik te vorm, te bely, te verkondig en te beoefen, word hierdeur beskerm. Godsdiensbeoefening mag in staatsinstellings of instellings wat deur die staat ondersteun word, plaasvind mits dit onder andere op ' $n$ billike grondslag geskied en die bywoning daarvan vry en vrywillig is.

(Rautenbach \& Malherbe 1994:13)

Ten opsigte van onderwys word akademiese vryheid aan universiteite en ander tersiêre instellings gewaarborg, asook regte op basiese onderwys en gelyke toegang tot onderwysinstellings, onderrig in die taal van keuse waar redelikerwys uitvoerbaar en waar uitvoerbaar, die oprigting van onderwysinstellings gebaseer op 'n gemeenskaplike kultuur, taal of godsdiens. In laasgenoemde instellings mag daar egter nie diskriminasie op grond van ras plaasvind nie.

(Rautenbach \& Malherbe 1994:16)

\subsection{Die Heropbou- en Ontwikkelingsprogram (HOP)}

' $n$ Verdere konteks wat vir Christelike onderwys belangrik is, is die Heropbou- en Ontwikkelingsprogram (HOP). Die HOP sluit aan by die Regering van Nasionale Eenheid se nasiebouprogram en strek sonder twyfel verder as die voorsiening van behuising, mediese dienste en onderwysfasiliteite aan minderbevoorregtes. Een van die noodwendige implikasies van die HOP is ' $n$ drastiese toename in die hoeveelheid anderkleurige leerlinge aan instellings wat voorheen eksklusief Afrikaans en Blank was. Dit beteken uiteraard dat die leerlingsamestelling ook godsdienstig minder homogeen sal wees as voorheen.

Aan die een kant moet daar sekerlik gewaarsku word teen die gebruik van die terme 'HOP' en 'nasiebou' as slagspreuke om na willekeur fondse, infrastruktuur en mensekrag te manipuleer tot voordeel van sekere belangegroepe in ons land. Aan die ander kant moet Christene die geleenthede wat die fokus van die HOP bied, aangryp: eerder as om nie-Christene uit onderwysinstellings met 'n Christelike etos te weer, behoort nie-Christene in Christelike onderwysinrigtings die liefde - maar ook die onontwykbare oproep - van die Here Jesus Christus self te leer ken. So kan die wanhopige sondaar homself weer ontdek en. leer waardeer as iemand wat vir God en vir God se kinders in Suid-Afrika belangrik is. Juis langs hierdie weg het Christene die geleentheid om ' $n$ bydrae te lewer tot ware versoening, tot opregte Christelike naasteliefde, en tot die vestiging van ' $n$ broodnodige Christelike werksetiek in Suid-Afrika. 


\subsection{Die Witskrif oor Onderwys en Opleiding}

Die Regering van Nasionale Eenheid se Witskrif oor Onderwys en Opleiding het in Maart 1995 verskyn. Dit volg op die publikasie van 'n konsepwitskrif in September 1994 wat groot openbare reaksie uitgelok het. Meer as seshonderd voorleggings is na aanleiding van die konsepwitskrif uit die breë gemeenskap ontvang, en moes verreken word in die uiteindelike Witskrif oor Onderwys en Opleiding. Hierdie Witskrif verteenwoordig verder ' $n$ kompromis tussen die groot politieke partye wat in die kabinet verteenwoordig is. Daar kan dus aanvaar word dat hierdie dokument die raamwerk verskaf vir alle nuwe onderwyswetgewing in die afsienbare toekoms.

Die vierde hoofstuk van die Witskrif spel die waardes en beginsels van onderwysen opleidingsbeleid uit, en bevat ' $n$ aantal uitsprake wat vir Christelike onderwys van groot belang is:

Ouers of voogde dra die primêre verantwoordelikheid vir die onderwys van hulle kinders, en het die reg om deur die staatsowerhede geraadpleeg te word oor die vorm wat onderwys moet aanneem en om deel te neem aan die beheer daarvan. Ouers het ' $n$ onvervreembare reg op keuse van die vorm van onderwys wat vir hulle kinders die beste is, veral in die vroeë jare van skoolonderwys, ongeag of dit deur die staat voorsien word, onderhewig aan redelike waarborge wat by wet vereis kan word. Die ouers se reg om te kies omvat die keuse van die taal en die kulturele of godsdienstige grondslag van die kind se onderwys, met inagneming van die regte van ander en die groeiende kind se reg om te kies.

(Witskrif 1995:21)

Dit vereis die aktiewe aanmoediging van wedersydse respek vir ons mense se uiteenlopende geloofs-, kulturele- en taaltradisies, hulle reg om dit in vrede en sonder belemmering te geniet en te beoefen, en die erkenning dat dit ' $n$ bron van krag vir hulle eie gemeenskappe en die eenheid van die nasie is.

(Witskrif 1995:22)

Hierbenewens bevestig die Witskrif die geleentheid wat die breë gemeenskap gegun sal word om op verskillende terreine by die herstrukturering van die onderwys betrokke te raak. Dit sluit ' $n$ sensitiewe saak soos kurrikulumontwikkeling in: 
Die Ministerie van Onderwys is verbind tot ' $n$ ten volle deelnemende proses van kurrikulumontwikkeling en -toetsing, waarin die onderwysprofessie, onderwyseropvoeders, vakadviseurs en ander leerpraktisyns saam met akademiese vakspesialiste en navorsers ' $n$ leidende rol speel. Die proses moet oop en deursigtig wees, en voorstelle en kritiek moet verkry word van enige persone en liggame met belange by die leerproses en leeruitkomste.

(Witskrif 1995:27)

Die Witskrif sluit aan by die tussentydse Grondwet van die Republiek van Suid-Afrika met verwysing na vryheid van godsdiens, gewete, oortuiging en uitdrukking in die onderwys (Artikel 14 [1]), en voeg by:

Hierdie individuele reg ontken nie die reg van ' $n$ persoon, met inbegrip van ' $n$ regspersoon, om ' $n$ onderwysinrigting gebaseer op 'n gemeenskaplike geloof, ooreenkomstig artikel 32 (c) tot stand te bring nie. So ' $n$ inrigting kan nie godsdienstige nakoming van studente wat hulle vryheid van gewete wil uitoefen, vereis nie.

(Witskrif 1995:43)

Ten opsigte van godsdiensbeoefening in staats- of staatsondersteunde onderwysinrigtings verwys die Witskrif na Artikel 14(2) van die grondwet en stel uitdruklik dat dit in sulke instellings kan plaasvind 'kragtens reëls deur ' $n$ toepaslike gesag vir daardie doel bepaal, mits sodanige godsdiensbeoefening op ' $n$ billike grondslag geskied en bywoning daarvan vry en vrywillig is' (Witskrif 1995:44).

\section{KONKLUSIE}

\subsection{Christelike waardes en norme, onderwys en opleiding, en wetgewing}

Dit is net ' $\mathrm{n}$ kwessie van tyd voordat die bestaande onderwyswetgewing in Suid-Afrika vervang sal word. Dit sluit in die artikels in die huidige onderwyswetgewing wat die Christelike aard van skole wetlik vaslê (Artikel 62 van Wet 70 van 1988, Artikel 34 van Wet 47 van 1963 en Artikel 3 van Wet 90 van 1979). Hierdie feit hoef egter nie betreur te word nie. Die betrokke Artikels was in elk geval problematies, aangesien dit die Christelike geloof by implikasie op alle leerlinge afgedwing het. Die praktiese 
toepassing van hierdie wetgewing in skoolverband, veral met betrekking tot die aanbieding van Bybelonderrig in skole, het bowendien dikwels mank gegaan aan innerlike oortuiging en toewyding - en dit is sonder twyfel die grootste struikelblok denkbaar in die oordra van Christelike norme en waardes.

Die aard van toekomstige onderwyswetgewing blyk duidelik uit die Witskrif oor Onderwys en Opleiding (Maart 1995). Hoewel daar geen wetlike of geïnstitusionaliseerde bepalings sal wees om ' $n$ Christelike waardestelsel in onderwys en opleiding te verseker nie, beskerm die Grondwet en die Witskrif nogtans ' $n$ aantal regte wat belangrik is vir die uitleef van Christelike waardes binne die raamwerk van onderwys en opleiding. Hieronder geld die reg op vryheid van geloof en gewete (Artikel 14[1] van die grondwet) en die reg 'om, waar dit uitvoerbaar is, onderwysinstellings gebaseer op ' $n$ gemeenskaplike kultuur, taal of godsdiens tot stand te bring, met dien verstande dat daar geen diskriminasie op grond van ras mag wees nie' (Artikel 32[C] van die Grondwet). Die erkenning van die regte van ouers en bestuursliggame om die aard en etos van ' $n$ onderwysinrigting op primêre, sekondêre én tersiêre vlak te bepaal, is van groot belang. Met verwysing na Artikel 14 van die Grondwet bevestig die Witskrif ook mense se reg om hulle geloof binne die konteks van die onderwys te bely en uit te leef (sien weer Afd 4.3 hierbo).

Indien die Christelike etos van ' $n$ onderwysinrigting egter misbruik word om anderskleuriges uit Blanke onderwysinrigtings te probeer hou, kan ' $n$ mens verwag dat daar groot druk sal ontstaan om die wetlike ruimte wat vir die uitlewing van Christelike norme en waardes gelaat word, te begin inperk, nie net by wyse van wetgewing nie, maar ook deur weerhouding of vertraging van staatsfinansiering, deur openbare uitsprake en protesaksies vanuit die gemeenskap. Maar meer nog, indien ons aan ons Christelike geloof ' $n$ etiket van eksklusiwiteit gee, of selfs net die indruk laat dat ons die Christelike karakter van onderwysinstellings as ' $n$ meganisme gebruik om rassisme te verskans, berokken ons self ons Christelike waardes en die naam van ons Here Jesus Christus onberekenbare skade. As Christene moet ons eerder die groot onderwysbehoeftes van die breë gemeenskap raaksien en help aanspreek. Indien ons bereid is om ons kundigheid en infrastruktuur tot beskikking van die breë gemeenskap te stel, sal ons ongekende geleenthede kry om ons Christelike norme en waardes aan groeiende getalle mense oor te dra.

\subsection{Geleenthede om Christelike norme en waardes in onderwys en opleiding uit} te bou

Die omwentelinge in onderwys en opleiding maak heelwat nuwe energie in die gemeenskap los, ook onder Christene. Dit skep vir Christene geleenthede om met nuwe ywer 
en toewyding ook op die terrein van onderwys en opleiding aan hulle waardes gestalte te gee. Ek wil graag ' $n$ paar voorbeelde uitlig.

Gedurende die volgende paar jaar sal ' $n$ stroom wetgewing oor onderwys en opleiding op nasionale en provinsiale vlak stellig die lig sien. In 'n gees van openheid word die gemeenskap telkens uitgenooi om op konsepwetgewing te reageer. Dit is kosbare geleenthede wat Afrikaanse Christene. en veral kerklike rade en kommissies vir onderwys en opvoeding, onder geen omstandighede deur hulle vingers mag laat glip nie.

By die opstel van nuwe kurrikula vir Godsdiensonderrig en Bybelkunde op skool en aan tersiêre inrigtings moet die Afrikaanse kerke aktief betrokke wees. Die bestaande kurrikula is verouderd en in vele opsigte onbevredigend. Nuwe relevante kurrikula kan van hierdie kursusse weer boustene in die geloofsgroei en lewe van groot getalle jongmense maak. Die Afrikaanse kerke moet egter besef dat hulle nie soos vroeër meer die pas kan aangee in hierdie proses nie, maar dat groter ekumeniese betrokkenheid met betrekking tot onderwysaangeleenthede van kardinale belang is.

Christene en kerke moet ook by die aanbieding van hierdie kursusse op skool aktief betrokke raak. Geen onderwyser mag verplig of gemanipuleer word om Bybelonderrig of Bybelkunde aan te bied nie - hierdie vormende kursusse moet uit vrye wil en innerlike oortuiging deur begeesterde Christene aangebied word. Onderwysinrigtings behoort ruimskoots van die hulp van plaaslike predikante, kerkraadslede en geskikte lidmate gebruik te maak.

Die groter rol van onderwysinrigtings se (bestuurs)rade wat reeds die afgelope aantal jare gestalte gekry het, word in die Witskrif oor onderwys en opleiding bevestig, en moet ten volle deur die plaaslike gemeenskap opgeëis word. Die belangrike rol wat goeie onderwysers, dosente en opleidingspersoneel speel om Christelike waardes aan leerlinge en studente oor te dra, kan nooit hoog genoeg aangeslaan word nie. Om hierdie rede is dit van kardinale belang dat bestuursrade die reg moet behou om onderwysers van hulle keuse aan te stel - en in staat moet wees om hierdie personeellede na waarde te betaal!

Die nuwe situasie waarin onderwys en opleiding in Suid-Afrika bedryf gaan word, sal ook nuwe eise an die kerk van Christus stel. Ek wil ook in hierdie verband die aandag op ' $n$ paar sake vestig.

Christene word tans meer toenemend aan mense met ander geloofsoortuigings blootgestel. Dit bring vrae na vore oor die herkoms, aard en gelykheid van godsdienste. Hierdie vrae mag en kan nie deur die onderwysowerhede aangespreek word nie. Die kerk sal hierdie vrae baie deeglik in sy kategese, prediking en ander verkondigingsgestaltes moet aanspreek.

In die opleidingsveld kan daar uiteraard nie aan die Christelike kerk voorkeur gegee word bo ander godsdienstige liggame nie. Tog sal die kerk deur middel van sy lidmate en amptelike vergaderings in die toekoms al hoe meer bedag moet wees op 
situasies wat Christene strem in die uitleef van hulle geloof. Dit geld veral die groeiende tendens om allerlei werksaktiwiteite vir Sondae te skeduleer. Opleidingsgeleenthede in die besonder mag nie 'n struikelblok word wat Christene verhoed om ten volle aan kerklike aktiwiteite deel te neem nie.

' $n$ Laaste saak raak die kundigheid waaroor Christene en dus ook die Afrikaanse kerke beskik. Die behoefte aan hierdie kundigheid in die verskillende plaaslike gemeenskappe sal waarskynlik toeneem. Tans berus die inisiatief in onderwys en opleiding by die nuwe regerings - waar Afrikaanse Christene helaas swak verteenwoordig is. Om hierdie kundigheid nie te verloor nie, en om Afrikaanse onderwysinrigtings met ' $n$ Christelike etos by te staan, moet die kerk dit ernstig oorweeg om saam met ander vennote ' $n$ toepaslike nie-regeringsinstelling tot stand te bring wat die beskikbare kundigheid kan benut en koördineer in diens van onderwyinrigtings met ' $n$ Christelike en Afrikaanse inslag.

Samevattend kan ons sê dat ons regte as Christene waarskynlik nie in die gedrang is nie, maar dat ons ons volle regte vir ons sal moet toeëeien. Meer nog - ons as Christene sal die nuwe geleenthede moet aangryp.

Ek wil hierdie artikel graag met ' $n$ beeld afsluit. Ons was voorheen in " $n$ klooster - veilig ommuur met allerlei vorme van wetgewing, reëls en regulasies wat ons teen ander oortuigings en waardestelsels beskerm het. Dit het ons invloed beperk en tot morele korrupsie in ons midde aanleiding gegee. Nou is ons in die wye, oop sendingveld - waar ons oortuigings en ons Christelike norme en waardes getoets gaan word. Maar juis die vryer kontak van hierdie nuwe omgewing, ook in onderwys en opleiding, bied ons die geleentheid om ons Christelike norme en waardes meer effektief aan die jeug van Suid-Afrika oor te dra. Dít is die antwoord op die aanvanklike vraag: só kan Christelike norme en waardes in die nuwe onderwysbestel tot hulle reg kom.

\section{Literatuurverwysings}

Gerber, A E 1978. Die kind-in-opvoeding, in Landman, WA (red), Opvoedkunde vir onderwysstudente. Stellenbosch: Universiteits-Uitgewers en -Boekhandelaars.

Landman, W A (red) 1978. Opvoedkunde vir onderwysstudente. Stellenbosch: Universiteits-Uitgewers en -Boekhandelaars.

Onderwysvernuwingstrategie: Bestuursoplossings vir onderwys in Suid-Afriká. Departement van Nasionale Opvoeding: Pretoria:

Onderwysvoorsiening in die $R S A$. Verslag van die hoofkomitee van die R G Nondersoek na die onderwys 1981. Pretoria: R G N.

Rautenbach, I M \& Malherbe, E F J 1994. Wat staan in die Grondwet? Johannesburg: Randse Afrikaanse Universiteit. 
Roos, S G 1978. Bedreiginge vir 'n Christelike en nasionale opvoeding, in Landman, W A (red), Opvoedkunde vir onderwysstudente. Stellenbosch: UniversiteitsUitgewers en -Boekhandelaars.

Witskrif oor onderwys en opleiding. Staatskoerant 357/16313. Pretoria: Departement van Onderwys. 